\title{
The Impact of Updated Soil Properties on the Development of Land Price in Selected Cadastral Area Near the Strongly Urbanized Areas
}

\author{
Jan Szturc ${ }^{*}$, Vítězslav Hybler ${ }^{2}$ \\ 1 Mendel University in Brno, Faculty of AgriSciences, Department of Applied and Landscape Ecology, \\ Zemedelska 1, 61300 Brno, Czech Republic \\ 2 Mendel University in Brno, Faculty of AgriSciences, Department of Agrochemistry, Soil Science, Microbiology \\ and Plant Nutrition, Zemedelska 1, 61300 Brno, Czech Republic \\ * Corresponding author's e-mail: jan.szturc@seznam.cz
}

\begin{abstract}
This paper deals with the development of soil characteristics and its impact on the land price determination in the model territory at the South Moravia region. The available data and map resources were used (price decrees, landuse maps) to evaluate the results. Data processing was performed using the ArcGIS software tools, which created the necessary map and statistical outputs. Within the selected time segments, the quantity and quality of agricultural land is reduced in individual periods up to the present. In most cases, agricultural land is urbanized in favor of city development. For the comparison of the future development, the potential future occupation of agricultural land, which is designed according to the current territorial plan of the municipality, was assessed as well. The article also evaluates the development of the land prices according to valid decrees (historical and current). Furthermore, on the basis of a comparison of the original and updated ESEU, the difference in the price of land in the area under consideration was evaluated. The results show that over the last 180 years, the land had a total value of over 20.6 million CZK within the ESEU (in today's prices), and according to the land-use plan, there would be another occupation in the total value of about 10 millions CZK. The results also show that the prices of the ESEU are currently $36 \%$ higher, on average, than in 2002. If this trend is maintained, a large loss of agricultural land can be expected in the future, coupled with possible problems of sustainable agriculture and, potentially, shortages of food resources.
\end{abstract}

Keywords: estimated soil-ecological unit, soil sealing, land price, land fund

\section{INTRODUCTION}

Bonitation and land valuation has more than a two-hundred-years tradition in the Czech Republic. It originated and evolved from the need to determine the production capacity of agricultural land, i.e. the yield from the land, only for the needs of state institutions to fairly allocate the land tax, to estimate purposes for the purchase, sale and exchange of agricultural land. The necessity to determine the production potential of the soil in the interests of its more rational use and protection came much later. Gradually, with the increase in soil fertility experience, features of the most fertile soils and ways of increasing fertility were described. With the development of natural sciences at the beginning of the 19th century, the knowledge on the soil properties was refined. The development factors also affect the social and economic factors.

In their present form, bonitations of agricultural land are the last step in the mapping, classification and evaluation of agricultural land in terms of pedological and agroecological properties. Bonitation classification of agricultural land and its economic valuation allow to differentiate the production capacity of soils across and within the cadastral territories and within the individual farms. After the introduction of ESEU into the Land Register, it is possible to evaluate and assess the production capacities on the individual agricultural land of each land owner.

On the basis of the results obtained from the comprehensive soil survey, a large number of 
basic units determined by the soil genesis and the soil substrate were identified and summed up to 1818 of the bonited (assessed) land-based units. Following the re-bonitations carried out in the 1990s, the final figure was 2199 land-based ecological units (Němec, 2001). According to the latest methodology (Novotný et al., 2013), this system was expanded by 138 new ESEU codes, as well as 59 codes that are no longer in the updated methodology. Altogether, 2278 ESEU codes are defined. All 2278 ESEUs will be available in practice after their economic evaluation and assignment of the protection class (SOWAC GIS).

Each ESEU is determined on the basis of a detailed assessment of the climate parameters, soil classification, characteristics of geological substrates, granularity, skeletality, water and air regime of soils, depth of soil profiles, slopes of land and their exposure. Each of these parameters has a numeric code, each ESEU is defined by a five-digit code.

Over the past 20 years, the agricultural land was devastated, due to water and wind erosion as well as insensitive large-scale farming. Therefore, it is necessary to approach the soil considerably in order to avoid its degradation by both erosion and unnecessary buildings on high quality soils.

The ESEU update is for identifying the changes in soil and climatic conditions of agricultural land by field research and to evaluate them against the conditions that characterize the currently established ESEU, for example, if significant changes occurred.

\section{Estimated Soil-Ecological Unit code structure}

It is five-digit code, which expresses the soil and climatic conditions that affect the production capacity of the land and its economic evaluation. These characteristics were established via legislation, and the procedure for their administration and the update is found in Decree No. 327/1998. As amended by Decree No. 546/2002, the ESEU valuation is done by Decree no. 441/2013.

\section{Defining digits of ESEU code}

1. The first digit of the code ESEU corresponds to the climatic region (marked with code $0-9$; climatic regions were allocated on the basis of documents of Hydro-meteorological Institute in Prague exclusively for the purpose of bonitation of agricultural land resources (BALR) and includes the areas with approximately identical climatic conditions for the growth and development of agricultural crops). In the Czech Republic, a total of 10 climatic regions were defined.

2. The second and third digits define the main soil unit (01-78). The main soil unit (MSU) groups the soil forms, related to environmental performance, which are characterized by morphogenetic soil type, subtype, soil-forming substrate, grit and some MSU pronounced slope, depth of soil profile and stoniness.

3. The fourth digit provides a combination of slope and exposure of land to the cardinal directions.

4. The fifth digit indicates the combination of the depth of the soil profile and its stoniness (Mašát, 2002), (SOWACGIS).

Designation of estimated soil-ecological unit code:

- X.xx.X.X. code of climatic region (0-9)

- x.XX.X.X. code of main soil unit (01-78)

- X.xx.X.X. associated code of slope and exposure (0-9)

- X.xx.X.X. associated code of stoniness and soil depth (0-9)

\section{METHODOLOGY AND DATA}

Statistical data, spatial raster data and vector data were used as the starting material. In order to achieve the results, land maps have already been used in eight time periods. The period of the second military mapping (1836-1852) was used as a starting point, followed by the dates of the third military mapping (1876-1878), 1950, 1990, 2006 and 2016. The current landscape plan of the municipality was also used. All the necessary data was exported from these maps, and then processed and evaluated using mathematical statistics. For data processing, creation of map outputs, comparison of information on the area of the taken bonited soil-ecological units, the methods and procedures contained in ArcGIS SW were used.

\section{Economical evaluation of agricultural land degradation by urbanization}

The Czech Republic introduced the "Land Evaluation Information System" in the 1970s to evaluate the agricultural land and its production 
capacity expressed in prices. This system contains the basic data on the land defined by using a 5-digit code, forming together an Evaluated SoilEcological Unit (ESEU). Each of the digits (or pair of digits) expresses a particular land characteristic. The system of evaluated soil-ecological units reflects all characteristics and differences in a particular agronomical area (soil, climatic and morphological conditions). Regionalization of individual ESEU and their corresponding codes is based on a digital collection of ESEU maps, using the borderlines surrounding individual ESEU surfaces with their numerical designation.

On the basis of many years of experience gained during the soil quality, it can be stated that the changes in soil properties due to erosion are manifested mainly by the shortening of soil profile, increase in the skeletality and changes in the classification of the main soil unit. By comparing the soil condition, the changes in soil characteristics can be determined and quantified by means of a valuation decree (see 441/2013).

The changes of these soil characteristics were used to assess the qualitative degradation of agricultural soil due to expansion of built-up areas. This assessment was divided into three time periods: second military mapping (1836-1852 to 2016); 1950-2016; 2016 with the official landscape planning of the village.

On the basis of the Decree No. 441/2013, the official price is fixed for every ESEU $\left(\mathrm{CZK} / \mathrm{m}^{2}\right)$. By comparing lost land due to the build-up and the price of land (Decree No. 441/2013) the total price of degraded land can be determined (Podhrázská et al., 2015; Náplavová, 2008; Szturc, 2014). This approach was applied to the assessment of economic impacts of soil sealing in the model location Dolní Heršpice.

Within this article, historical and newly updated EPEUs were also processed due to the availability of EPEU data, which were also evaluated through ArcGIS software. This data was provided by the State Land Office - the Brno office.

\section{Characteristics of the area}

Dolní Heršpice is a former village, now a district or a quarter of the city of Brno, and its cadastral territory with an area of 312.55 ha forms the part of Brno-south. It lies on the west bank of the river Svitava along both banks of the river Svrat$\mathrm{ka}$, which flows through the neighboring east of the original former village.
The development of Dolní Heršpice consists of two distinctly separated parts. On the one hand, it is a mainly western industrial part, stretching along the Vídeňská street, which runs through the important E461 highway leading through the tram line. On the west of this street there is a large shopping centre, Futurum Brno. To the south of this commercial centre, in the southwest of the cadastre, the garden lands are linked to similar plots of land in the adjacent cadastral area of Př́žrenice village. The second eastern part of the settlement is made up of the original village, situated on the right bank of the river Svratka, and on the left bank of the Svratka, situated in the area of Avion Shopping Park Brno. As in the case of Př́zřenice, extensive parts of arable land are found between the two parts of Dolní Heršpice, which is also much smaller on the eastern edge of the cadastre. The core of the original village is the South Square, which houses the chapel of St. Catherine from Siena.

\section{RESULTS}

\section{ESEU occupations}

The first ESEU projects were processed and evaluated. Gradually, the digitized historical and current maps were exported to the actual evaluation. For the sake of clarity, ESEU occupation was divided into three time series (1836-1852 to 2016; 1950-2016; 2016 with the actual official landscape planning - LS plan). Each such time series will give an indication of the individual ESEU, its size, percentage representation and total price according to the currently valid price order (441/2013). In addition, the total ESEU occupation for the given time period and the total cost captured by the ESEU were evaluated. On the basis of this analysis, the way development of the built-up area leads to the acquisition of quality soils in the Czech Republic can be determined (Table 1 and Figure 2).

While evaluating of the decrease of the area of individual ESEU, it was found that the best quality of land is used for the development of the urban area (ESEU code: 2.01.00, 2.0.10, 2.08.10, 2.10.00).

The total land occupation was 148.85 ha between the second military mapping (1836-1852) and present time (2016). According to appraisal order no. $441 / 2013$, the price per square meter 


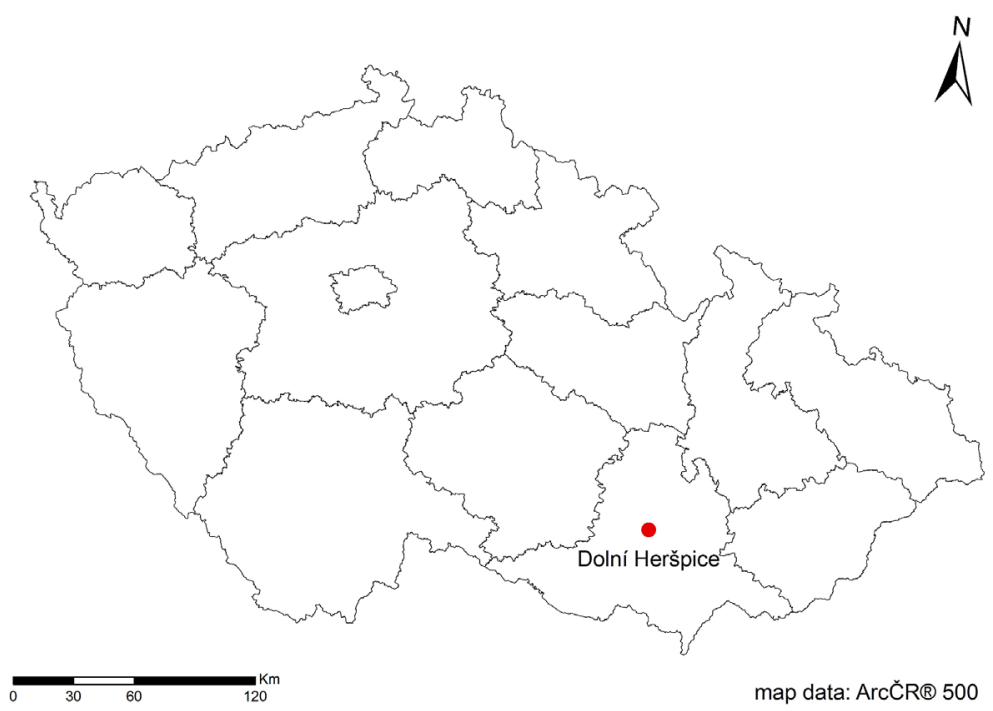

Fig. 1. Location of the area

Table 1. Sealing of individual ESEU and total cost of degraded soil

\begin{tabular}{|c|c|c|c|c|c|c|c|c|c|c|}
\hline \multirow[b]{2}{*}{ ESEU } & \multirow{2}{*}{$\begin{array}{c}\text { Price of } \\
\text { ESEU } \\
(\mathrm{CZK} / \\
\left.\mathrm{m}^{2}\right)\end{array}$} & \multicolumn{3}{|c|}{$2 m m-1950$} & \multicolumn{3}{|c|}{ 1950-2016 } & \multicolumn{3}{|c|}{ 2016-LS plan } \\
\hline & & ha & $\%$ & $\begin{array}{l}\text { Total price } \\
\text { (CZK) }\end{array}$ & ha & $\%$ & $\begin{array}{l}\text { Total price } \\
\text { (CZK) }\end{array}$ & ha & $\%$ & $\begin{array}{l}\text { Total price } \\
\text { (CZK) }\end{array}$ \\
\hline 2.01 .00 & 17.22 & 0 & 0 & 0 & 0.65 & 0.49 & $111,930.00$ & 17.76 & 25.33 & $3,058,272.00$ \\
\hline 2.01 .10 & 15.43 & 0 & 0 & 0 & 6.36 & 4.80 & $981,348.00$ & 0 & 0 & 0 \\
\hline 2.03 .00 & 17.91 & 0.27 & 1.65 & $48,357.00$ & 0.04 & 0.03 & $7,164.00$ & 0.76 & 1.08 & $136,116.00$ \\
\hline 2.06 .00 & 13.77 & 0 & 0 & 0 & 0.00002 & 0.00002 & 2.75 & 0 & 0 & 0 \\
\hline 2.08 .10 & 11.78 & 4.82 & 29.63 & $567,796.00$ & 34.61 & 26.10 & $4,077,058.00$ & 15.46 & 22.05 & $1,821,188.00$ \\
\hline 2.10 .00 & 15.82 & 5.23 & 32.15 & $827,386.00$ & 23.01 & 17.36 & $3,640,182.00$ & 13.53 & 19.30 & $2,140,446.00$ \\
\hline 2.37 .16 & 1.59 & 0 & 0 & 0 & 0.02 & 0.015 & 318.00 & 0.28 & 0.40 & $4,452.00$ \\
\hline 2.56 .00 & 14.02 & 5.95 & 36.57 & $834,190.00$ & 67.87 & 51.19 & $9,515,374.00$ & 22.32 & 31.84 & $3,129,264.00$ \\
\hline 2.58 .00 & 10.39 & 0 & 0 & 0 & 0.007 & 0.0053 & 727.30 & 0.0003 & 0.00043 & 31.17 \\
\hline Total & 0 & 16.27 & 100 & $2,277,729.00$ & 132.58 & 100 & $18,334,104.05$ & 70.11 & 100 & $10,289,769.17$ \\
\hline
\end{tabular}

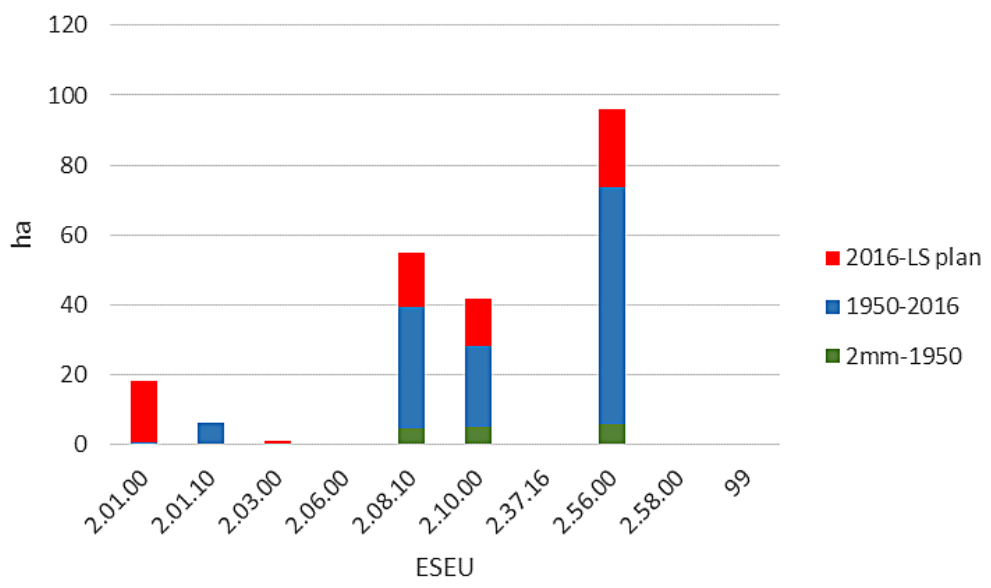

Fig. 2. Graphical representation of individual sealed Evaluated Soil-Ecological Units

can be assigned to the ESEU. According to the ESEU and their respective prices, the price of occupied areas was calculated. The results show that the total cost captured by the ESEU between the period of the second military mapping and the present is 20,608,833.05 CZK. From 2016 to a 


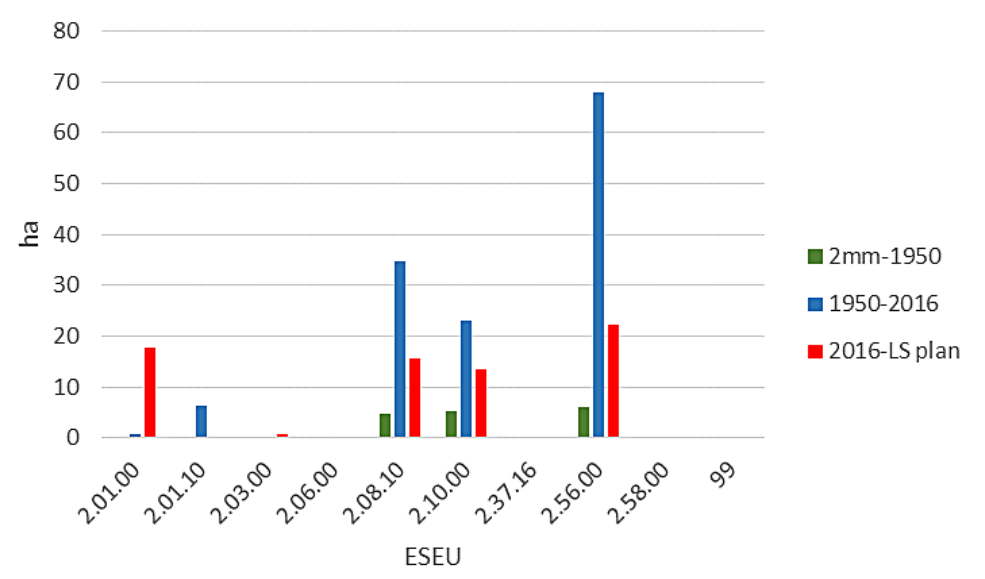

Fig. 3. Graphical representation of total sealed Evaluated Soil-Ecological Units

state that is proposed by the land-use plan, another 70 ha of soils will be occupied, representing another occupation of ESEU in the total value of 10,289,769.17 CZK.

\section{Comparison and evaluation of ESEU before and after updating}

The updating of the agricultural land fund in the cadastral area of Dolní Heršpice was made on the basis of complex land consolidation, where updated ESEUs served for a more precise valuation of land within the land consolidation (at the end these land consolidation were not implemented). This is the first update of the ESEU in this cadastre, which was carried out by the Land Office Brno in 100\% reinsurance by Research institute for soil and water conservation (VÚMOP), Brno department.

Table 2 summarizes the observed values before and after the updating of the soil-ecological

Table 2. Comparison of the rate before and after the ESEU update

\begin{tabular}{|c|c|c|}
\hline ESEU & Not current (ha) & Current (ha) \\
\hline 2.01 .00 & 114.59 & 22.03 \\
\hline 2.01 .10 & 7.07 & 6.37 \\
\hline 2.03 .00 & 11.54 & 1.07 \\
\hline 2.06 .00 & 0.0018 & 0.000018 \\
\hline 2.08 .10 & 49.49 & 72.60 \\
\hline 2.10 .00 & 0 & 47 \\
\hline 2.37 .16 & 0 & 2.87 \\
\hline 2.55 .00 & 0.000041 & 0.000026 \\
\hline 2.56 .00 & 120.68 & 158.02 \\
\hline 2.58 .00 & 3.77 & 2.60 \\
\hline 99 & 5.42 & 0.01 \\
\hline Total & 312.56 & 312.57 \\
\hline
\end{tabular}

units. It can be seen that after the ESEU update, the individual ESEU measurements have been changed. The update also includes the newly defined codes (2.10.00 and 2.37.16) which were not present in the previous state.

Figure 4 clearly shows the course of the ESEU before and after the update. On the basis of this analysis it can be concluded that the ESEU update in this locality was mainly reflected in the change in the boundaries of each individual ecological unit, compared to the original state. The new result is also the definition of the new ESEU codes done by precise, more detailed work, and by the degradation processes.

Furthermore, according to individual price decrees, the prices of ESEU per square meter were compared, and the percentage price increasements were calculated from 2002 to the present.

The table shows the evolution of the price of ESEU according to historically valid price decrees and the current price regulation, it can also be stated that the prices of ESEU are currently $36 \%$ higher than in 2002, on average.

This table accurately displays all ESEU codes that are located in the cadastral area, which are attributed to the calculated data (area $\mathrm{x}$ price according to the relevant decree). The columns of the ESEU price are the prices of both ESEU and total prices.

\section{CONCLUSIONS}

The results show the fact that over the last decade, there has been a slight increase in the price of land per $\mathrm{m}^{2}$, mainly due to its revaluation. The results also show that in the cadastral area of Dolní Heršpice the total land price increased by $34 \%$ 


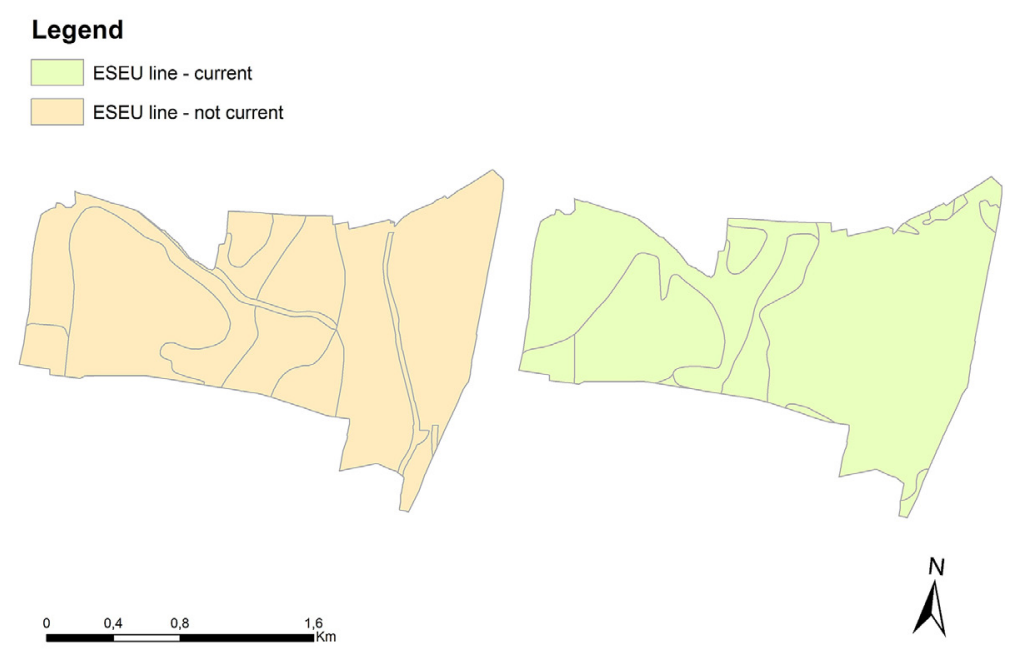

Fig. 4. Map of the former state of ESEU and of the newly actualized situation

Table 3. Description of ESEU in Dolní Heršpice cadastre

\begin{tabular}{|c|c|}
\hline ESEU & Text characteristics ESEU \\
\hline 2.01 .00 & \multirow{2}{*}{$\begin{array}{l}\text { Flat and moderately sloped Haplic Chernozems, soils with thick humus horizon, with crumb to granular structure, } \\
\text { developed from loose carbonate substrates, deep soil }\end{array}$} \\
\hline 2.01 .10 & \\
\hline 2.03 .00 & $\begin{array}{l}\text { Chernozem mainly flat or full, with omnidirectional exposure and a total skeletal content of up to } 10 \% \text {. Soils deep in } \\
\text { a warm, slightly dry climatic area and highly productive. }\end{array}$ \\
\hline 2.06 .00 & Vertic Chernozems, heavy to highly heavy, on heavy bedrock \\
\hline 2.08 .10 & Washed-off (eroded) Haplic Chernozems with cultivated substrate, in moderately sloped and sloped terrain \\
\hline 2.10 .00 & Flat and moderately sloped Haplic Luvisoils, with heavier bottom, skeletonless, deep, moderately sloped \\
\hline 2.37 .16 & $\begin{array}{l}\text { Cambisols, rankers, lithic Leptosols mostly on mild slopes, with omni-directional exposure and a total skeletal } \\
\text { content of } 25-50 \% \text {. The soil is shallow in a warm, slightly dry climatic region and productively low. }\end{array}$ \\
\hline $\begin{array}{l}2.55 .00 \\
2.58 .00\end{array}$ & $\begin{array}{l}\text { Fluvisols predominantly on a plane or a complete plane, with omni-directional exposure and a total skeletal content } \\
\text { of up to } 10 \% \text {. Soils deep in a warm, slightly dry climatic region and low production. }\end{array}$ \\
\hline 2.56 .00 & Flat and moderately sloped Fluvisols, deep soil profile, slightly dry climatic region \\
\hline 99 & No agricultural land \\
\hline
\end{tabular}

Table 4. Evolution of ESEU prices in 2002-2013

\begin{tabular}{|c|c|c|c|c|}
\hline ESEU & $\begin{array}{c}\text { Price of EPEU by the } \\
\text { decree no. 540/2002 (CZK/ } \\
\left.\mathrm{m}^{2}\right)\end{array}$ & $\begin{array}{c}\text { Price of EPEU by the } \\
\text { decree no. 3/2008 (CZK/ } \\
\left.\mathrm{m}^{2}\right)\end{array}$ & $\begin{array}{c}\text { Price of EPEU by the } \\
\text { decree no. 441/2013 } \\
\left(\mathrm{CZK} / \mathrm{m}^{2}\right)\end{array}$ & $\begin{array}{c}\text { \% difference between the } \\
\text { prices of 2002 and 2013 }\end{array}$ \\
\hline 2.01 .00 & 12.86 & 15.01 & 17.22 & 34 \\
\hline 2.01 .10 & 11.51 & 13.45 & 15.43 & 34 \\
\hline 2.03 .00 & 13.38 & 15.61 & 17.91 & 34 \\
\hline 2.06 .00 & 10.25 & 12.00 & 13.77 & 34 \\
\hline 2.08 .10 & 8.75 & 10.27 & 11.78 & 34 \\
\hline 2.10 .00 & 11.80 & 13.79 & 15.82 & 53 \\
\hline 2.37 .16 & 1.04 & 1.39 & 1.59 & 35 \\
\hline 2.55 .00 & 6.76 & 7.98 & 9.15 & 34 \\
\hline 2.56 .00 & 10.44 & 12.22 & 14.02 & 35 \\
\hline 2.58 .00 & 7.70 & 9.06 & 10.39 & 3 \\
\hline
\end{tabular}

compared to the total price determined in accordance with the Decree of year 2002. Subsequent update of the estimated soil-ecological unit confirmed the total increase of the price by $26 \%$ to the year 2002; however, compared to the current total price of the non-updated ESEU, there was a significant decrease in the total land price in the area (-8 \%, i.e. 2,606,111.75 CZK). This significant difference can generally be attributed to the more intensive agricultural management of the territory 
Table 5. Total land price comparison (area $\mathrm{x}$ price of ESEU per $\mathrm{m}^{2}$ ) according to individual decrees

\begin{tabular}{|c|c|c|c|c|}
\hline ESEU & $\begin{array}{l}\text { The total price of the } \\
\text { original EPEU (by the } \\
\text { decree no. 540/2002) }\end{array}$ & $\begin{array}{l}\text { The total price of the } \\
\text { original EPEU (by the } \\
\text { decree no. 3/2008) }\end{array}$ & $\begin{array}{l}\text { The total price of the } \\
\text { original EPEU (by the } \\
\text { decree no. 441/2013) }\end{array}$ & $\begin{array}{l}\text { The total price after update } \\
\text { of EPEU (by the decree no. } \\
441 / 2013 \text { ) }\end{array}$ \\
\hline 2.01 .00 & 14735867.88 & 17199484.98 & 19731854.19 & 3793568.76 \\
\hline 2.01 .10 & 813389.72 & 950485.81 & 1090408.17 & 982290.00 \\
\hline 2.03 .00 & 1544450.86 & 1801859.33 & 2067347.90 & 191390.20 \\
\hline 2.06 .00 & 187.78 & 219.84 & 252.27 & 2.48 \\
\hline 2.08 .10 & 4330198.78 & 5082416.16 & 5829684.75 & 8552041.34 \\
\hline 2.10 .00 & 0 & 0 & 0 & 7434956.41 \\
\hline 2.37 .16 & 0 & 0 & 0 & 45654.00 \\
\hline 2.55 .00 & 2.77 & 3.27 & 3.75 & 2.38 \\
\hline 2.56 .00 & 12598858.99 & 14746940.32 & 16919157.39 & 22154755.62 \\
\hline 2.58 .00 & 290603.93 & 341931.38 & 392126.60 & 270062.08 \\
\hline Total & 34313560.71 & 40123341.09 & 46030835.02 & 43424723.27 \\
\hline
\end{tabular}

Table 6. Comparison of price land in Dolní Heršpice

\begin{tabular}{|l|c|c|}
\hline \multicolumn{1}{|c|}{ Specification } & Price (CZK) & Diff. (\%) \\
\hline $\begin{array}{l}\text { The total price of the original } \\
\text { EPEU (by the decree no. } \\
540 / 2002)\end{array}$ & $34,313,560.71$ & \\
\hline $\begin{array}{l}\text { The total price of the original } \\
\text { EPEU (by the decree no. } \\
441 / 2013)\end{array}$ & $46,030,835.02$ & 34 \\
\hline $\begin{array}{l}\text { The total price after update } \\
\text { of EPEU (by the decree no. } \\
441 / 2013)\end{array}$ & $43,424,723.27$ & 26 \\
\hline
\end{tabular}

with the possible erosion development, which results in the reduction of soil quality. By the assessing of soil bonitation parameters through the updated ESEUs, the economic impacts of erosion processes in the period between bonitations can be quantified to a certain level. The agronomicecological characteristics of the area, expressed in the code of the evaluated (bonited) soil-ecological units, are influenced by external factors, especially the way of the arable soil farming. The Czech Republic is characterized by a high ratio of arable land, and consolidation of original owners plots into large production blocks. This approach to land use has the effect, in the long run, on developing of erosion processes associated with degradation on eroded soils. The qualitative changes of these soils can be identified through the field surveys combined with the ESEU update. In many cases, the original ESEUs are then re-coded into other groups of soils. Thus, the main soil units can be changed; the erosion of the soil profile is also reflected in the reallocation of the 5th ESEU code number. The reallocation of land to other agronomic-ecological categories results in the price change of the respective land in accordance with the valuation decree (Decree
No. 441/2013). Due to erosion processes, the ESEU price may be reduced, which means significant economic losses for landowners. This fact is generally not well-known and reflected by the society, but it may, in summary, have a considerable negative impact from the point of view of economic damage to particular owners and landlords, who may eventually ask for compensations of the damages. Moreover, it can also be dangerous from point of view of the whole society, by reducing the agricultural production base and the national food security.

\section{Acknowledgements}

The paper was elaborated within the unspecific research of the Department of Applied and Landscape Ecology, AgriFaculty of the Mendel University in Brno.

\section{REFERENCES}

1. Decree No. 540/2002 Sb. of December 31, 2002, for execution of the Act on Property Valuation (Valuation Decree). Czech Republic (in Czech).

2. Decree No. 3/2008 Sb. of February 1, 2008, for execution of the Act on Property Valuation (Valuation Decree). Czech Republic (in Czech).

3. Decree No. 441/2013 Sb. of December 17, 2013, for execution of the Act on Property Valuation (Valuation Decree). Czech Republic (in Czech).

4. Geoportal SOWACGIS, Základní informace o BPEJ [online]. [2015-14-04]. Available from: <http:// geoportal.vumop.cz/index.php?project=zchbpej>

5. Mašát K. Metodika vymezování a mapování botiovaných půdně ekologických jednotek. 3rd ed. Praha, Výzkumný ústav meliorací a ochrany půdy. 2002. 
6. Náplavová M. Vlastnosti rebonitovaných zemědělských půd v katastru obce Moravský Písek. Brno, Diplomová práce (Ing.). Mendelova univerzita v Brně, Fakulta Agronomická, Ústav agrochemie, půdoznalství, mikrobiologie a výživy rostlin, 2008, 26-05.

7. Němeček J. Taxonomický klasifikační systém půd ČR. 2nd ed. Praha: CZU, 2011.

8. Novotný i., Vopravil J. Metodika mapování a aktualizace BPEJ. Praha: Výzkumný ústav meliorací a ochrany půdy. 2013.
9. Podhrázská J., Kučera J., Karásek P., Konečná J. Land degradation by erosion and its economic consequences for the region of Jihomoravský (Czech Republic). Soil and Water Research, 2015, 10(2), 105-113.

10. Szturc J. Srovnání rebonitace zemědělského půdního fondu ve vybraných lokalitách v okrese FrýdekMístek. Brno, Diplomová práce (Ing.) Mendelova univerzita v Brně, Fakulta Agronomická, Ústav agrochemie, půdoznalství, mikrobiologie a výživy rostlin, 2014, 23-05. 